\title{
Ergonomics and the inclusion of disabled people in the Brazilian job market
}

\author{
Martins, L. B. ${ }^{a}$, Cabral, A. K. P. S. ${ }^{\text {b, }}$, \\ ${ }^{a}$ Senior Lecturer, Department of Design, Federal University of Pernambuco, Av. Professor Moraes Rego, 1235, \\ Cidade Universitária, 50670-901, Recife-PE, Brazil.laurabm@folha.rec.br \\ $\mathrm{b}$ Senior Lecturer, Department of Occupational Therapy, Federal University of Pernambuco, Av. Professor \\ Moraes Rego, 1235, CEP 50670-901, Cidade Universitária, Recife, PE, Brazil.
}

\begin{abstract}
The inclusion of persons with disabilities (PD) has been widely discussed in Brazil. The main purpose of this paper is to identify the contributions of ergonomics in the process of including disabled people in the job market and to discuss the situation in Brazil. It was found that ergonomics is an important tool within organizations. Using it allows space, work stations and tools to be matched workers' needs, including those with disabilities, on behalf of whom it is necessary to adjust the demands of work to their specific needs. However, further research is needed in Brazil on the existing methods of ergonomic intervention for this population in order to suit their needs and optimize potential.
\end{abstract}

Keywords: ergonomics, work, disabilities.

\section{Introduction}

The inclusion of people with disabilities (PD) has been widely discussed in Brazil, which in line with what the World Health Organization (WHO) advocates, based on a biopsychosocial model of health (International Classification of Functioning, Disability and Health - ICF) argues for the need to provide actions to prompt or maintain the active participation of the individual in society, even in the face of incapacitating diseases [18].

Professional inclusion is a right, regardless of the type of disability that a person experiences or their level of impairment. For Tortosa et al. (1997), the participation of PDs in society implies that their abilities, needs and limitations should be considered in the design of living and working conditions [22].

In this context, the ergonomic approach becomes essential, as it is by this means that most PDs are able to return to their previous job or learn a new job, often with greater determination and enthusiasm than people who do not have a disability.
Ergonomics plays an important role as it studies the interactions between humans and machines by aiming to optimize well-being and the overall performance of systems, by adapting the ambients of work to man. It has its disposal the tools needed to analyze the factors that influence the fit between human capacity and the requirements of the job [22].

This scientific discipline is capable of supplying solutions for specific problems by matching the task and items of equipment to human needs, taking into account individuals' (motor, sensory, cognitive, psychosocial) abilities, including those of PDs, and is thus an important instrument within organizations.

In Brazil, the Ministry of Work and Labor created a Regulatory Norm regarding Ergonomics, NR - 17, which lays down the parameters which may permit adapting working conditions to workers' psychophysiological characteristics so as to provide maximum comfort, safety and efficient performance [14].

\footnotetext{
* Corresponding author. E-mail: laurabm@folha.rec.br._Department of Design, Federal University of Pernambuco, Av. Professor Moraes Rego, 1235, Cidade Universitária, 50670-901, Recife- PE, Brazil.
} 
This norm states that to evaluate the adaptation of working conditions to workers' psychophysiological characteristics, it falls to the employer to conduct an ergonomic analysis of the job, and that it should, as a minimum, address the working conditions related to lifting, transporting and unloading materials, to furniture, equipment and the environmental conditions of the job and to the organization of work itself.

However, it is worth stressing that the NR should not be used alone, since it does not address all the aspects relevant to the ergonomic analysis. There is often the need for a deeper study, covering other variables addressed by Ergonomics, regarding the job, working environment or the workers themselves, besides those cited in the norm.

With regard to the design of jobs for PDs, Ergonomics becomes an indispensable tool, since besides its facilitating the configuration of the post, it considers the principles of accessibility and setting up technical forms of assistance that enable work to be carried out on an equal footing with people who do not have a disability [17].

As per Zurimendi (1994), when applied to special populations, such as PDs, Ergonomics is not shown to present a focus that is different from other situations, which is to say that it will always adapt work to the characteristics of the worker [24]. Tortosa et al. (1997) add that, in the case of PDs, who do have functional limitations, this adaptation is necessary, since PDs depend much more on the environment than those who do not have limitations [22].

Therefore, PDs' workplace should allow for or facilitate the development of individual skills and abilities, including preventing the progression of the deficiencies present and/or the emergence of new ones.

Within this context, the distinction between disability and disadvantage has great practical relevance because it is exactly this concept of disadvantage that will allow Ergonomics to act in an attempt to improve or change the situation. The removal of architectonic barriers, the design of special products, and the ergonomic configuration of the workplace are examples of actions that can avoid the inability of the subject becoming a disadvantage or, at least, seeing to it that that the disadvantage created by the environment is minimal. Thus, the concept of disadvantage is clearly an ergonomic one, since it is a result of the relationship between the individual and his/her environment in a given situation [22].
Through the ergonomic analysis, it is possible to create designs for environments and jobs tailored to the capabilities and limitations of the PDs, by acting on issues such as accessibility, universal design, adaptation of physical structures and tools of the job and organizational systems, and moreover it also covers setting up technical forms of assistance.

For the ILO (1997), the main objectives of adapting jobs to DPs are: the creation of safe working conditions, so that the PD does not place him/herself or others at risk; and the prevention of occupational disadvantages, and of worsening the existing incapacity or disability [15].

Corroborating the above quote, based on the ergonomic analysis and intervention on the problems encountered, and using principles of universal design and accessibility, it is possible to maximize PDs' residual capacities, to create the conditions for carrying out tasks with maximum efficiency, safety, comfort, equal conditions, a minimum risk to workers, without provoking aggravation and/or the appearance of new disabilities or incapacities [4, 15].

Likewise, Sassaki (2006) argues that the performance efficiency of PDs in their work environment will depend mainly on internal company factors, including the adaptation of apparatus, machinery, tools and equipment as well as adapting the workplaces (physical access) [21].

Santos and Fialho (1997), taking a broader view, report that for this an evaluation needs to be conducted that takes in the furniture, lighting, internal and external movements, use of toilets, attendance at community venues for relaxation and leisure, an analysis of the task compatible with the individual's ability, a decrease in using up energy (stress of movement), by the successive use of motor skills and the very rigid organization of work [20].

Given these issues, Tortosa et al. (1997) consider the fundamental role of Ergonomics, since it offers important contributions to the analysis of the subject and work, and by so doing to direct the selection, design and redesign of the job, amid the ongoing monitoring of the compatibility between the worker and the task [22 ].

Thus, so that the PD can have his/her full potential used to advantage in the market, Ergonomics should be considered in its broader recommendations, as resolving the problems of adapting the environment, taking the necessary measures for the comfort of the employees in his/her work environment work, and a multidisciplinary team should be used to develop tools that facilitate the life of that worker, such as devices that lend help, and to do all this using 
ergonomic methodologies which de facto ensure the suitable selection of this range of the population and their placement into accessible and appropriate jobs.

However, as per IIDA (1990) there are various fields of work as yet little explored by Ergonomics, such as the situation which involves PDs in the Brazilian labor market [9]. Moraes (2001), corroborating this statement, points out that in Brazil there is an enormous shortfall in the production of ergonomic research studies in this area, especially with regard to ergonomic methodologies that target analysing and adapting jobs for PDs [12].

Thus, this paper sets out to present a survey on the contributions of Ergonomics in the process of including people with disabilities in the labor market, by discussing the Brazilian reality.

\section{The contribution of Ergonomics to adapting jobs to people with disabilities.}

Sassaki (2006) argues that, as with any other person, there is a need to assess their competences and skills, and thus to check on what possibilities for occupational functions there are to make a successful placement [21].

Chi (1999) and Tortosa et al. (1997) report that the job which is specifically designed or redesigned is the best method for the PD's real insertion or reinsertion into work $[1,21]$. However, this includes a complex, multifaceted job, and requires the collaboration of various professionals, doctors, experts, psychologists, occupational therapists, educators, designers, architects, businessmen, and so forth, and the person involved. The success of this work depends on many factors, including the analysis of the characteristics of the subject (functional capacity, attitudes, skills, preferences, educational background, experience, interest in the job, difficulties, etc.), of the demands of the job and characteristics of task.

Tortosa et al. (1997) explain that there is a need to compare demands and capacities, i.e. to evaluate the capabilities of the individual and to determine the demands and requirements of the activity [21]. The goal is that the demands do not exceed the capabilities and the post is accessible and safe. Therefore, they present the model in Figure 1 cited by Wieland and Laurig (1988) and Jochheim et al. (1993).

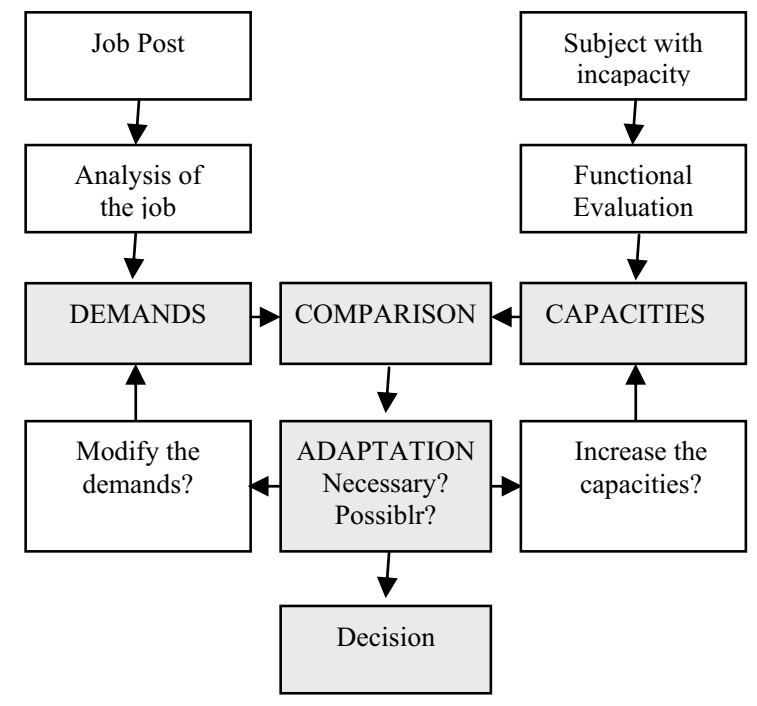

Figure 1. Model for adapting job posts (Source: Tortosa et al., 1997).

Under this model, the analysis of the demands should describe the physical and mental requirements of the work-related tasks, with details as to the strength needed, range of motion, resistance, dexterity, coordination, vision, etc. In addition to which there are the demands of the task themselves, the environmental and organizational conditions of the work and accessibility of the job.

As per the Fundación Mapfre (1997), task analysis is one of the main stages of the ergonomic program, along with the evaluation methods. This consists of describing the work situation, and making a relationship between activity, production and health [2].

For Laville (1977), the task is about achieving the objective, getting the result. Thus, task analysis should include a description and analysis of the requirements of the task (objectives or conditions of the context), the task environment (factors in the work situation) and the behavior of the task (real actions performed) [12].

As to evaluating capacities, i.e. the functional evaluation of the worker should determine the ability to perform the essential activities of the job, after analyzing the demands of the tasks previously carried out. To do so, it includes a series of assessment procedures to determine the subject's attitude to work. This is not a traditional medical examination. It differs from this mainly in its direction and to a lesser extent, in its content. In the medical examination, it defines whether the worker is fit for a particular job 
or if he/she is able to perform the essential tasks of a job. In functional evaluation, the nature of the job, the person's physical, sensory and mental capacity, and other factors are considered such as acquired skills, academic background, preferences and motivation.

In short, the comparison itself does not determine the future job position. In fact, there is a need to define to what extent abilities and skills can be improved through training and practice and/or if the demands of work can be modified, for example, by reducing the workload. After checking the possibilities of organizational adjustments, the decision is taken about the situation which may be acceptable, with or without physical changes, or unacceptable, in this case, there being a need to seek alternative work and to repeat the process.

It is valid to point out that the professional rehabilitation process is essential and should be offered in hospitals and in the community so as to compensate or recover functional losses and to minimize the effects of sensory, physical or mental impairments. A wide focus needs to be used, and for it to be understood that certain attitudes and environmental conditions can interfere with the disability, apart from the limitations inherent to the subject. It is also essential to develop the PD's capacity and at the same time, to eliminate environmental barriers and discriminatory attitudes of professionals, entrepreneurs and society.

The model for adapting jobs presented has, inter alia, the following applications [22]:

- Selecting the most suitable job - based on comparing the demands of the job and the PD's capacities

- Modifying or redesigning the workplace - a comparison between demands and capacities, and the analysis of ergonomic risks indicates the indispensable changes needed in the workplace to accommodate a particular subject and the priority of these changes.

- Education and training - a comparison between demands and capacities allows the individuals' educational and training needs to be detected, as to plan for the programs necessary to achieve them.

Garcia and Burgos (1994) add that the application of Ergonomics to DPs has specific characteristics and difficulties, among which are methodological difficulties, it being necessary to conduct an overall and specific evaluation of the PD and his/her work, with careful data collection [3].

\section{Discussion on Ergonomics and the process of including people with disabilities in the labor market: the Brazilian context}

In Brazil, approximately $23.91 \%$ of the population has some type of disability, equivalent to 45.6 million people, among who only 9 million work, despite Brazilian law having legal instruments to ensure the inclusion of this population in the labor market [8]. As an example, law $n^{\text {o. }} 8.213 / 1990$ lays down that companies with more than 100 employees must hire PDs who should account for between $2 \%$ and $5 \%$ of their staff.

Oliveira (2002) mentions that Brazil has a high rate of underemployment and unemployment, limited industrial development and that the demand for labor is much higher than the supply [16]. This reality differs from the world scene in which Ergonomics is increasingly being applied to all kinds of work, making it easier to ensure work to PDs in occupations that have already been adapted for workers who do not have a disability, apart from the government covering the costs to do so or offering incentives to companies.

In this regard, Guerin et al (2001) report that in Brazil, people responsible for planning, selection processes and staff training, such as human resource teams and management, trying to adapt human means to the technical and organizational characteristics of the system of production [5]. Since companies think that PDs are unable to do all types of formal work, the latter are often placed in lighter jobs [10].

The Ministry of Labour and Employment of Brazil (2007) points out that registering a PD in Brazil is usually done through records coming from public information systems such as the National Employment System (SINE in Portuguese), Centers and Technical Units of Professional Rehabilitation of the National Institute for Social Security (INSS in Portuguese), the Information System of the National Coordination unit for the Integration of People with Disabilities (SICORDE in Portuguese), or via NonGovernmental Organizations (NGOs), Sites and Employment Agencies [14].

It is further observed that some companies, unaware of the mechanisms for widening the employability of PDs and with a view only to satisfying meeting the quota requirement, have based their se- 
lection and hiring on the supposed apparent lower limitation. They select only those workers who fit into the legal definition described, since they do not require physical adjustments to be made or, at most, a minimal investment in this direction, and rarely invest in technical forms of assistance.

It has been observed that deaf people or people with minor restrictions on their mobility have been preferred in this regard, which creates an understandable dissatisfaction from others with moderate or severe disabilities, but with the potential to work, if adequate training is provided, which is greater than that of many of those who are hired.

On this subject, Nambu (2003) warns that there are no specific professions for people with certain disabilities. On the contrary, there are professionals with disabilities who have skills for various occupational functions.

Therefore, it is concluded that every disabled person has different skills that would be better taken advantage of in functions that require them, and Ergonomics enables these skills to be identified and the job for this population to be adjusted.

To analyze working conditions, it is necessary to define the factors that represent the content of the work, in all its main aspects, so as then to evaluate them by means of objective and/or subjective criteria, by having recourse to the most different methods of evaluation that are available, objective and subjective.

\section{Ergonomics in adapting jobs: methods of ergonomic intervention drawn up by Brazilian researchers}

As mentioned, although Brazilian law guarantees PDs minimum access to jobs, the literature points to significant difficulties in selecting and placing these subjects in positions that match their potential, despite the limitations.

According to Oliveira (2002), there is no special ergonomic approach for this group, but the application of Ergonomics has some specific characteristics, such as those related to applying methods and techniques [16].

The main methods used to analyse and adapt jobs for PDs in Brazil are: Ergonomic Work Analysis (AET in Portuguese), Macro-ergonomic Analysis of Labor (AMT in Portuguese)) and the Systemic Approach of the Human-Task-Machine System.

The Ergonomic Analysis of Work Analysis (AET, in Portuguese), by Santos and Fialho (1997), pro- poses to understand demand, prescribed and real work, its problems and possible solutions. For this approach, of the real context of work, qualitative methods are generally used [20]. An example that can be cited is thee moment of confrontation between 'prescribed and real' work in which the company's prescriptive documents are set against what is observed in the reality of the job and described by the workers who do the activities. Only at this stage, three tools from the qualitative approach are used: document analysis, direct observation (participant or not) and the interview or focus group.

The Macro-ergonomic Analysis of Work (AMT in Portuguese) proposed by Guimarães (1999) is a method of ergonomic action with a participatory approach which, when applied to companies, has the methodological orientation of action research [7]. This is a type of social research with an empirical base. It is conceived and carried out in close association with an action or with the resolution of a collective problem. In it, researchers and the participants who are representatives of the situation or problem are involved in a co-operative or participatory way, as proposed by Thiollent (1994) [7]. AMT sets out, above all, to contribute to improving the quality of life and work and, in this way, part of the organization undergoes the process until the job is reached.

The Systemic approach of the Human-Machine Task System, of the authors Moraes and Mont'Alvão Moraes (2003), proposes matching the system and its components to the characteristics of the worker, by means of an ergonomizing intervention comprising five phases: ergonomic evaluation (mapping the ergonomic problems of the company); ergonomic diagnosis (analysis of the prioritized problems and predictive tests; ergonomic design (adapting workstations, equipment and tools to the physical, psychological and cognitive characteristics of the worker), evaluation, validation and/or ergonomic testing (return to the users of design proposals), ergonomic detailing and optimization (design review of the design) [13].

Garcia and Burgos (1994) emphasize that the methods and techniques of the ergonomic analysis of work in Brazil, often do not address the particular needs of this population [3]. Thus, some authors have adapted tools from the ErgoDis/IBV Method and the MAECS Method, created specifically to analyse and compare the PDs' work profile with the requirements of the task in order to detect imbalances in the system subject-work and propose recommendations to improve the job. There is a need to understand that, by being about PDs, generalizations should not be made, 
since similar disabilities often do not generate similar difficulties and, for their part, distinct disabilities can generate the same difficulties.

Guérin et al. (2001) argue that there is no single model of ergonomic action, except for some fundamental principles in common, the construction of each ergonomic action in companies takes on a particular approach [5].

Under this outlook, the collection of data should be the most detailed one possible, and this also puts into effect analysing and recognizing the symptoms.

Therefore, it is argued there is a need to improve and enrich ergonomic methodology through a richer and more global view of the subject with a disability, especially in relation to data collection.

Although the AET, AMT and Systemic Approach Methods are widely used in Brazil, they cannot always be used in isolation, or if they are, there is a need to recognize the possibility of adapting and complementing their tools, since PDs have different and particular demands.

\section{Closing Remarks}

As shown in the foregoing, it was verified that Ergonomics is an important tool within organizations, since it enables spaces, offices and work tools to be made suitable for all workers, including those with disabilities.

Adapting jobs to PDs should be the result of comparing the demands and requirements of the job with the worker's skills and abilities such that the demands do not exceed nor are much less than workers' capacities to meet them. There must be a balance between these two domains, the goal of ergonomic intervention, which may point to modifying the demands or increasing capacities.

In this context, it becomes important to insert the concepts of Universal Design and technical forms of help to give PDs the conditions to overcome their limitations and provide them with opportunities. Without these concepts, added to ergonomic intervention, the risk occurs of making it difficult to develop PDs' individual capacities and skills, of underestimating their work potential or moreover, in more severe cases, to provoke the progression of the disabilities present and/ or the emergence of new ones .

Finally, the conclusion is drawn that in Brazil, studies focused on the inclusion of PDs make use of methods and techniques for the ergonomic analysis of work that do not address the particular needs of this population. Therefore, it is necessary to investigate other experiences in different contexts in order to understand their specific applications and characteristics and thus make their use suitable and feasible for our population.

\section{References}

[1] Chi, C. A study on job placement for handicapped workers using job analysis data. International Journal of Industrial Ergonomics, v. 24, p. 337-351, 1999.

[2] Fundación Mapfre. Manual de Ergonomia. 2. Ed. Madrid: Mapfre, 1997.

[3] García, M.; Burgos, C. Ergonomia para personas com discapacidad. In: Metodologias y Estratégias para la Integracíon Laboral. Madrid: FUNDACIÓN MAPFRE MEDICINA, 1994.

[4] Gualberto Filho, A. et al. Uma visão ergonômica do portador de deficiência. In: VII Congresso Latino-Americano de Ergonomia. I Seminário Brasileiro de Acessibilidade Integral. XII Congresso Brasileiro de Ergonomia, 2002, Recife/PE, Anais...Recife/PE, 2002.

[5] Guérin, F. et al. Compreender o trabalho para transformá-lo: a prática da Ergonomia. Editora Edgard Blücher LTDA, 2001.

[6] Guimarães, L. B. de M. Ergonomia de Produto. 5ed. Vol 1. Série monográfica Ergonomia. Porto Alegre: FEENG, 2004.

[7] . Intervenção Macroergonômica em empresa do setor eletromecânico: um estudo de produtividade. In: I Encontro África-Brasil de Ergonomia, V Congresso LatinoAmericano de Ergonomia, IX Congresso Brasileiro de Ergonomia, III Seminário de Ergonomia da Bahia. Anais do ABERGO 1999. Salvador, 1999.

[8] IBGE - Instituto Brasileiro de Geografia e Estatística, 2011.

[9] Iida. Ergonomia: projeto e produção. $2^{\mathrm{a}}$ ed. São Paulo: Edgard Blücher, 2005.

[10] Landau, K. The right person at the right place: improved job opportunities for disabled persons. In: International Ergonomics Association. San Diego, 2000. Anais virtual...San Diego: IEA 2000/HFES 2000.

[11] Laville, A. Ergonomia. São Paulo: E. P. U., EDUSP, 1977.

[12] Moraes, A. Ergonomia nas Américas. Gramado: XI Congresso Brasileiro de Ergonomia. Súmula de Mesa Redonda, 2001.

[13] Moraes, A.; Mont'Alvão, C. Ergonomia: Conceitos e aplicações. 3. ed. Rio de janeiro: A. de Moraes, 2003.

[14] MTE - Ministério do Trabalho e Emprego. A Inclusão das Pessoas com Deficiência no Mercado de Trabalho. 2. ed. Brasília: MTE, SIT, 2007.

[15] OIT - Organização Internacional do Trabalho. Adaptação de ocupações e o Emprego do Portador de Deficiência. Brasília: CORDE, 1997.

[16] Oliveira, S. C. F. de. Análise Ergonômica do Posto de Trabalho de uma Pessoa Portadora de Deficiência Física: estudo de caso. Dissertação de mestrado. João Pessoa: UFPB, 2002. $103 \mathrm{p}$.

[17] Oliveira, S. C. F. et al. Adaptação de postos de trabalho ocupados por pessoas portadoras de deficiência física. In: XI Congresso Brasileiro de Ergonomia, Gramado, 2001. Anais virtual... Gramado: ABERGO, 2001.

[18] OMS - Organização Mundial de Saúde. Classificação Internacional de Funcionalidade, Incapacidade e Saúde CIF. São Paulo: USP, 2003. 
[19] Ribeiro, J. N. Uma Contribuição da Ergonomia à Inserção do Portador de Deficiência no Mercado de Trabalho no Setor Calçadista. Dissertação de mestrado. Departamento de Pós-graduação em Engenharia de Produção. João Pessoa, UFPB, 101 p., 2005.

[20] Santos, N. dos; Fialho, F. A. P. Manual de analise ergonômica no trabalho. 2. ed. Curitiba: Gênesis, 1997.

[21] Sassaki, R. K. Inclusão: construindo uma sociedade para todos. 7. ed. Rio de Janeiro: WVA, 2006.
[22] Tortosa, L. et al. Ergonomia y Discapacidad. 1. ed. Madrid: Ministerio de Trabajo y Asuntos Sociales, 1997.

[23] Vidal, M. C. R. Guia para Análise Ergonômica do Trabalho na Empresa. Rio de Janeiro: Virtual Científica, 2003.

[24] Zurimendi, M. M. Conceptos de Ergonomia: critérios para La adaptación persona-puesto. In: Metodologias y Estratégias para La Integracíon Laboral. Madrid: Mapfre, 1994. 